\title{
Correction to: Blood transcriptomic discrimination of bacterial and viral infections in the emergency department: a multi-cohort observational validation study
}

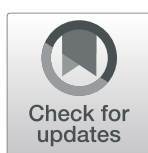

\author{
Dayle Sampson ${ }^{1}$, Thomas D. Yager ${ }^{1}$, Brian Fox', Laura Shallcross², Leo McHugh', Therese Seldon', \\ Antony Rapisarda ${ }^{1}$, Roslyn A. Hendriks ${ }^{1}$, Richard B. Brandon ${ }^{1}$, Krupa Navalkar' ${ }^{1}$, Nandi Simpson ${ }^{3,4}$, Sian Stafford ${ }^{3}$, \\ Eliza Gil ${ }^{3}$, Cristina Venturini ${ }^{3}$, Evi Tsaliki ${ }^{3}$, Jennifer Roe ${ }^{3}$, Benjamin Chain ${ }^{3}$ and Mahdad Noursadeghi ${ }^{3,4^{*}}$
}

\section{Correction to: BMC Med 18, 185 (2020) https://doi.org/10.1186/s12916-020-01653-3}

Following publication of the original article [1], it was brought to our attention that the member of the collaborating team at Immunexpress Roslyn A. Hendriks, had initially been omitted from the authorship of the article due to an oversight.

Roslyn A. Hendriks was involved in the original conception of the Septicyte TRIAGE signature, but had since left the Immunexpress team. The authors feel that her intellectual contribution to the development of this signature merits her inclusion in the authorship of the article.

The full and correct authorship has been updated in the original article and included in the author list of this Correction.

The 'Authors' contributions' section is also corrected to read: DS, TY, RB, RH and MN conceived and designed the study. NS, SS, EG, ET and JR performed sample processing and/or data collection. DS, BF, LS, LM, TS, AR, $\mathrm{KN}, \mathrm{CV}, \mathrm{BC}$ and $\mathrm{MN}$ performed the data analysis. DS, TY and $\mathrm{MN}$ wrote the manuscript with input from all the authors. All authors read and approved the final manuscript.

\section{Author details}

${ }^{1}$ Immunexpress, Seattle, WA, USA. ${ }^{2}$ Institute for Health Informatics, University College London, London, UK. ${ }^{3}$ Division of Infection and Immunity, University College London, London, UK. ${ }^{4}$ National Institute for Health Research

University College London Hospitals Biomedical Research Centre, London, UK.

Published online: 12 September 2020

\section{Reference}

1. Sampson D, et al. Blood transcriptomic discrimination of bacterial and viral infections in the emergency department: a multi-cohort observational validation study. BMC Med. 2020;18:185. https://doi.org/10. 1186/s12916-020-01653-3.
The original article can be found online at https://doi.org/10.1186/s12916020-01653-3.

*Correspondence: m.noursadeghi@ucl.ac.uk

${ }^{3}$ Division of Infection and Immunity, University College London, London, UK ${ }^{4}$ National Institute for Health Research University College London Hospitals Biomedical Research Centre, London, UK

Full list of author information is available at the end of the article

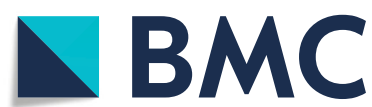

(-) The Author(s) 2020 Open Access This article is licensed under a Creative Commons Attribution 40 International License, which permits use, sharing, adaptation, distribution and reproduction in any medium or format, as long as you give appropriate credit to the original author(s) and the source, provide a link to the Creative Commons licence, and indicate if changes were made. The images or other third party material in this article are included in the article's Creative Commons licence, unless indicated otherwise in a credit line to the material. If material is not included in the article's Creative Commons licence and your intended use is not permitted by statutory regulation or exceeds the permitted use, you will need to obtain permission directly from the copyright holder. To view a copy of this licence, visit http://creativecommons.org/licenses/by/4.0/ The Creative Commons Public Domain Dedication waiver (http://creativecommons.org/publicdomain/zero/1.0/) applies to the data made available in this article, unless otherwise stated in a credit line to the data. 